\title{
Blood Pressure Differences in Nephrotic Syndrome Patients with Steroid Resistant Nephrotic Syndrome Patients and Steroid Sensitive Nephrotic Syndrome
}

\author{
Muhammad Akbar*, Oke Rina Ramayani, Gema Nazri Yanni \\ Department of Child Health, Faculty of Medicine, Universitas Sumatera Utara, Medan, Indonesia
}

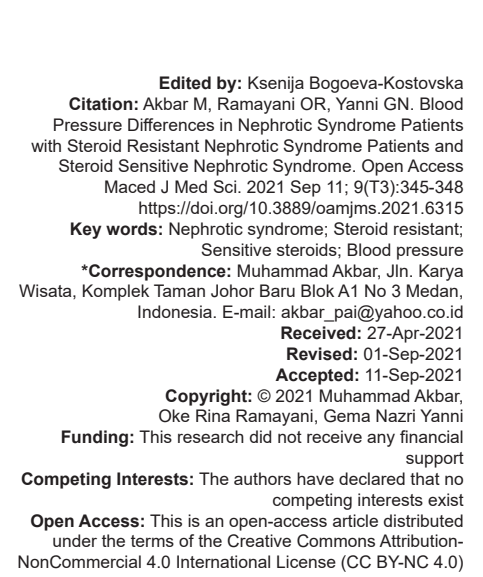

Introduction

Hypertension that occurs in nephrotic syndrome (NS) is an event that will cause a poor prognosis in cases of NS both in the Steroid Resistant NS (SRNS) group and in the steroid sensitive NS (SSNS) group [1]. According to a 2011 study in Bangladesh found, more hypertension incidence was found in SRNS compared to the SSNS group [2]. However, in another study in Manado, the average systolic and diastolic blood pressure was higher in the SSNS group than in the SRNS group [3].

NS is most commonly found in boys (with a male ratio: female 1.5-2:1) where most sufferers are children from the Asian continent [4]. According to the response to steroids, SN can be classified into two, namely, SSNS and SRNS [1]. Syndrome nephrotic sensitive steroid cover $80-90 \%$ syndrome while the rest is SRNS [2].

Proteinuria is one of the signs of NS [1]. Proteinuria is a condition in which the selectivity of glomerulus is disrupted so that proteins can be found in the urine [5]. A 2006 study of 29 children found a link between proteinuria and hypertension in 14 children [6].
Research in Indonesia 2019 on 484 schoolchildren aged 12-14 without symptoms found incidence of hypertension $12.9 \%$ and proteinuria $7.42 \%$ [7].

Hypertension that occurs in children aged $<1$ year and $>8$ year in children with renal impairment causes a poor prognosis [8]. Hypertension is more common in SRNS than SSNS ( $p>0.05)$, steroid therapy is associated with the incidence of hypertension in an SN treatment regimen $(p<0.01)$ [2]. Patient SSNS has a higher average systolic and diastolic blood pressure than SRNS, but this hypertension event is not statistically meaningfully related to SRNS and SSNS [3]. Almost the same research was also conducted by Mamesah et al. at RSUP Prof Dr. R. D. Kandou Manado. They found that SRNS patients had a higher average systolic and diastolic blood pressure than SSNS, and this incidence of hypertension was not associated with the incidence of SRNS and SSNS [9].

There were differences in blood pressure in both the SRNS and SSNS groups from several studies to see the difference in blood pressure of SSNS and SRNS sufferers at The General Hospital of Haji Center Adam Malik Medan. 


\section{Methods}

This study is a correctional study conducted in NS patients treated in the nephrology division from July 2020 to September 2020. The size of the samples in this researcher was calculated based on a categorical formula of no pairs. Calculations were carried out using a 95\% confident interval with a sample count of at least 22 patients. Informed consent obtained from all participants involved in the study, inclusion criteria are NS patients aged 1-18 years; patients have been getting steroid treatment for 4 weeks. Exclusion criteria are patients with acute or chronic renal failure, patients with chronic diseases such as severe malnutrition, pulmonary tuberculosis and malignancy.

Characteristic data of study subjects such as clinical manifestations and demographic data, physical examination and anthropometry collected during outpatient, blood pressure examination conducted using sphygmomanometer, and proteinuria check by Sysmex XN 1000.

\section{Data analysis}

Univariate analysis was conducted to obtain the spread of characteristics of the research sample. Normal distributed numerical data is presented in standard mean and deviation, in addition to being presented in maximum or minimum values. Categorical data are shown in percentages and frequencies. Chi-Square test was to assess gender characteristic differences, Mann-Whitney test to assess differences in systolic and diastolic blood pressure. The WallisKruskal test was used to compare degree of proteinuria in both groups. Proteinuria's relationship with blood pressure was assessed with the Kruskal-Wallis test. Data processing was conducted using Statistical Package for Social Sciences for Windows (SPSS) version 24.0, 2016 with a $p<0.05$ significance level and a $95 \%$ confidents interval.

\section{Ethical considerations}

This study was approved by Health Research Ethics Committee Medical Faculty, Universitas Sumatera Utara.

\section{Results}

In this study, each group of 25 SRNS and 25 SSNS children who met the criteria for inclusion and exclusion were involved in this study. Characteristic data showed that the distribution of male children was highest in the SRNS group of $18(72 \%)$ and the distribution of many female children in the SSNS group $17(68 \%)$ from this data there is a meaningful difference with $p=0.005$. Median age in the SRNS group was 10 years and in the SSNS group of 12.5 years with a minimum age of almost the same in both groups. In systolic blood pressure values were found to be cyclical differences in both groups with a value of $p=0.024(p<0.05)$, where in the SSNS group it was found to be a higher systolic median than in the SRNS group. In the diastolic blood pressure value, there was no significant difference in both groups with a value of $p=0.354(p>0.05)$ with the median equal at $70 \mathrm{mmHg}$.

Table 1: Subject characteristics

\begin{tabular}{|c|c|c|c|}
\hline Subject characteristics & SRNS $(n=25)$ & SSNS $(n=25)$ & $\mathrm{p}$ \\
\hline Gender, n (\%) & & & $0.005^{\mathrm{a}}$ \\
\hline Male & $18(72)$ & $8(32)$ & \\
\hline Female & $7(28)$ & $17(68)$ & \\
\hline Age, mean (SD), years & $10(8.4-17.8)$ & $12.5(3.1-17.8)$ & $0.432^{b}$ \\
\hline Body weight, mean (SD), kg & $32.92(16.12)$ & $39.30(16.81)$ & $0.178^{\mathrm{c}}$ \\
\hline Body height, mean (SD), cm & $131.40(28.35)$ & $136.76(22.19)$ & $0.460^{\circ}$ \\
\hline \multicolumn{4}{|l|}{ Blood pressure } \\
\hline Systolic, median (min-max) mmHg & $100(90-140)$ & $110(100-170)$ & 0,024 \\
\hline Diastolic, median (min-max) mmHg & $70(60-100)$ & $70(60-100)$ & 0,358 \\
\hline Proteinuria, $\mathrm{n}(\%)$ & & & $0,092^{\mathrm{d}}$ \\
\hline Negative & $11(44)$ & $12(48)$ & \\
\hline+1 & $11(44)$ & $4(16)$ & \\
\hline+2 & $3(12)$ & $8(32)$ & \\
\hline+3 & 0 & $1(4)$ & \\
\hline
\end{tabular}

The basic characteristic data of research subjects are shown in Table 1 and Figures 1 and 2.

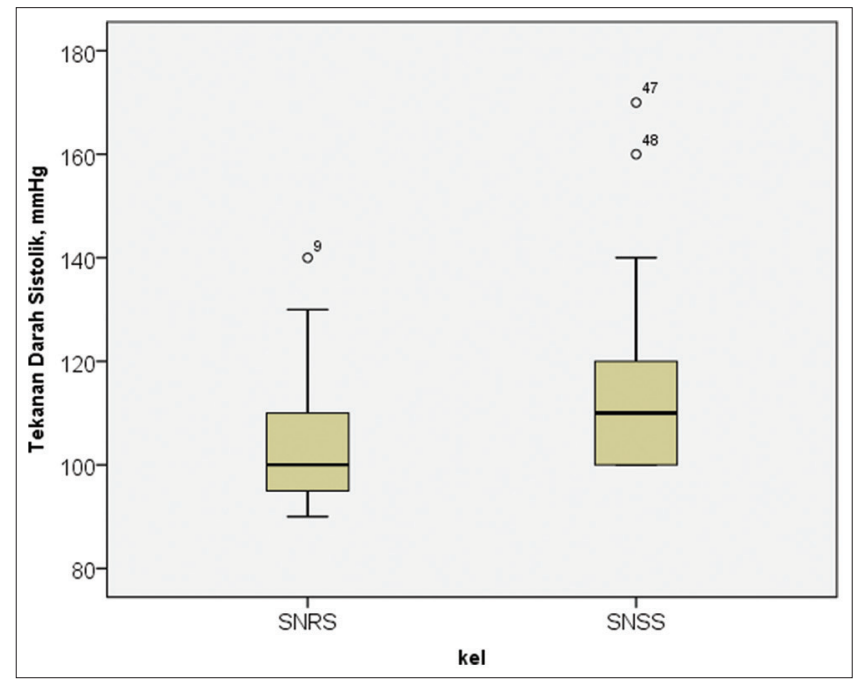

Figure 1: Systolic blood pressure boxplot chart in steroid-resistant nephrotic syndrome (NS) and steroid sensitive NS groups

There was no correlation between proteinuria levels and median blood pressure and systolic blood pressure in both the SSNS and SRNS groups. In the SSNS group proteinuria negative and +2 found the median systolic and diastolic values were higher than others $p=0.597$ and SRSS $p=0.088$ but meaningless. In the SRNS group had a median systolic value equal to all three degrees of proteinuria. At diastolic values, the SRNS group found higher median values in proteinuria +1 and +2 compared to proteinuria negative. The correlation proteinuria 


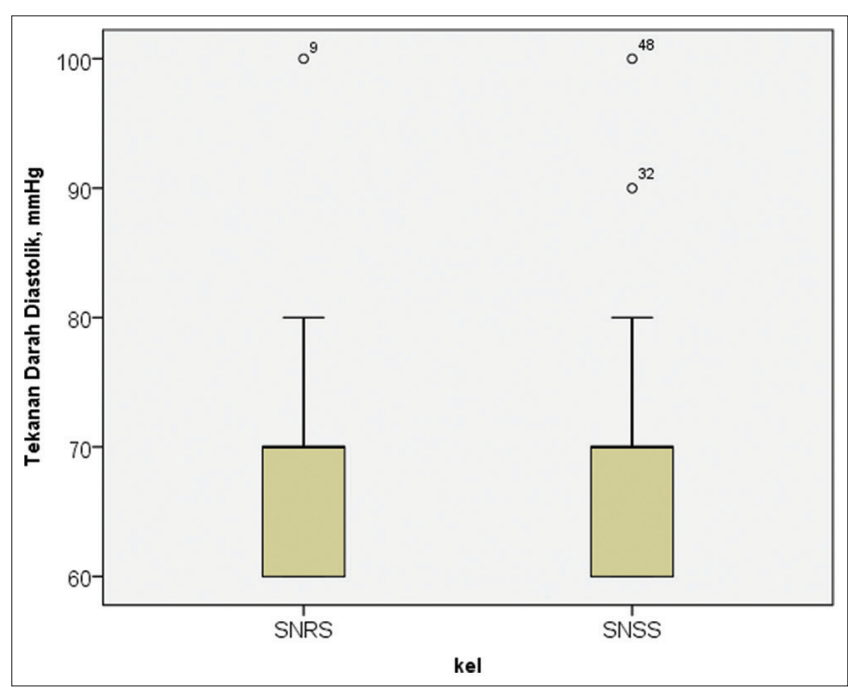

Figure 2: Diastolic blood pressure boxplot chart in steroid-resistant nephrotic syndrome (NS) and steroid sensitive NS groups

and blood pressure in SRNS and SSNS are shown in Table 2.

Table 2: Proteinuria's relationship with blood pressure in the SRNS and SSNS groups

\begin{tabular}{|c|c|c|c|c|c|}
\hline $\begin{array}{l}\text { SSSNS } \\
\text { groups }\end{array}$ & $\mathrm{n}$ & $\begin{array}{l}\text { Systolic BP, Median } \\
\text { (range), } \mathrm{mmHg}\end{array}$ & $p$ & $\begin{array}{l}\text { Diastolic BP, Median } \\
\text { (range), } \mathrm{mmHg}\end{array}$ & $p$ \\
\hline \multicolumn{6}{|l|}{ SRNS } \\
\hline \multicolumn{6}{|l|}{ Proteinuria } \\
\hline Negative & 11 & $100(90-130)$ & 0,556 & $60(60-80)$ & 0,528 \\
\hline+1 & 11 & $100(90-140)$ & & $70(60-100)$ & \\
\hline+2 & 3 & $100(90-100)$ & & $70(60-70)$ & \\
\hline \multicolumn{6}{|l|}{ SSNS } \\
\hline \multicolumn{6}{|l|}{ Proteinuria } \\
\hline Negative & 12 & $110(100-170)$ & 0,597 & $70(60-90)$ & 0,088 \\
\hline+1 & 4 & $105(100-130)$ & & $60(60-70)$ & \\
\hline+2 & 8 & $110(100-160)$ & & $70(70-100)$ & \\
\hline+3 & 1 & 100 & & 70 & \\
\hline
\end{tabular}

\section{Discussion}

NS in children is the most commonly found disease of the child's kidneys [10], [11]. NS is a clinical syndrome with symptoms of massive proteinuria $\left(\geq 40 \mathrm{mg} / \mathrm{m}^{2} \mathrm{LPB} / \mathrm{h}\right.$ or protein/creatinine ratio in urine while $>2 \mathrm{mg} / \mathrm{mg}$ or dipstick $\geq 2+$ ), hypoalbuminemia $\leq 2.5 \mathrm{~g} / \mathrm{dL}$, edema, and can be accompanied by hypercholesterolemia [2]. NS incidence in children in the United States and the United Kingdom is 2-4 new cases per 100,000 children per year [4]. In developing, the incidence is higher. In Indonesia, it is reported to be $6 / 100,000$ per year in children under the age of 14 [1].

In this study, we divided NS patients into two groups with the same proportion to reduce bias, the proportion of male gender in the SRNS group was more than in the female gender, but in the SSNS group it was found that the female gender proportion was more than the proportion of male sex. This is directly proportional to the prevalence of NS in children from the Asian continent where the prevalence of males is $1.5-2: 1$ of females [3].

Diagnosis of NS in patients under 1 year and above 8 years of NS should be performed renal biopsy before obtaining immunosuppressive therapy including steroids, because at this age the incidence of NS is an idiopathic type [8]. About $50 \%$ of children affected by NS are 1 year 6 months to 5 years old; $75 \%$ are younger than 10 years old [11], [12]. This was different in our study where the median age in this study was found at age 10 in the SRNS group and the average age of 12.5 years in the SSNS group.

The incidence of hypertension in children is about $20 \%$ caused by kidney disease [9]. Hypertension can be found in disease condition or in the course of NS disease due to steroid toxicity [1]. Corticosteroids can cause hypertension through the effects of coracoid minerals is by deflating the retention of sodium and water in the kidneys, expanding plasma volume and ultimately increasing blood pressure [13]. Etiology hypertension in NS is multifactor, that is, related to renal and non-renal intrinsic factors and the serviceman with extrinsic/environmental factors [14]. The underfill hypothesis states that sodium retention in NS is mainly due to reduced circulation volume due to fluid shift from intravascular to interstitial compartments due to reduced plasma oncotic pressure by hypoalbuminemia. This change activates the retention of sodium and water in the kidneys. While the overfill hypothesis states that the retention of sodium reflects the absence of intrinsic defects in the kidneys in dealing with sodium, which, in turn, leads to an expansion of volume [15]. In new, in our study, there was a higher increase in systolic blood pressure in the SSNS group compared to the significant SRNS group, but there was no difference in diastolic blood pressure in the SRNS and SSNS groups. This compares with a 2011 study in Bangladesh in which there were more hypertension events found in the SRNS group than SSNS $(p>0.05)$ [2] and in line with research in Indonesia 2016 where blood pressure found in the SSNS group was higher than the SRNS group but not statistically meaningful [3]. Another study by Mamesah 2019 found the average systolic and diastolic blood pressure of the SRNS group compared to the SSNS group [9]. Other studies that support our study have a high prevalence of hypertension in the SRNS and SSNS groups where the prevalence of hypertension in different patient populations with SNs ranges from 8\% to $59.1 \%$ [14]. Research by Kontchou 2009 mentioned the discovery of $65 \%$ prevalence of hypertension in the SSNS group [16].

In our study assessed the relationship of proteinuria degrees with high systolic and diastolic blood pressure found no meaningful relationship in both groups $(p>0.05)$. This is incompatible with a 2006 study by Seeman that found a link between proteinuria and hypertension in 14 healthy children with abnormal kidney ultrasound results [6]. Research in Indonesia 
on 494 children in 2019 also found the incidence of hypertension and proteinuria in schoolchildren 12-14 years without symptom [7].

\section{Conclusion}

There were significant differences in systolic blood pressure in both the SRNS and SSNS groups with higher systolic blood pressure medians in the SSNS group and no difference in diastolic blood pressure in both groups. The high prevalence of the SSNS group emphasizes that blood pressure monitoring in NS patients requires strict treatment to monitor further complications.

\section{References}

1. Beattie J. Nephrotic syndrome. In: Beattie J, editors. Guideline for the Management of Nephrotic Syndrome. Renal Unit Royal Hospital for Sick Children Yorkhill Division. $1^{\text {st }}$ ed. Scotland: Renal Clinicians Group; 2007. p. 2-8.

2. Roy RR, Islam R, Matin A, Khan R, Muinuddi G, Rahman H, et al. Relationship of childhood idiopathic neprhotic syndome with asthma, hypertension, complement $\mathrm{C}_{3}$, urinalysis. Bangladesh J Child Health. 2011;35(1):11-5. https://doi.org/10.3329/bjch. v35i1.10367

3. Mamesah RS, Umboh A, Gunawan S. Hubungan aspek klinis dan Laboratorium dengan sindrom nefrotik pada Anak. J E Clin. 2016;4(1):349-53. https://doi.org/10.35790/ecl.4.1.2016.10981

4. Krishnan RG. Nephrotic syndrome. Pediatr Child Health. 2012;22(8):337-40.

5. Viswanath D. Nephrotic syndrome in children. J Indian Acad Oral Med Radiol. 2013;25(1):18-23.

6. Seeman T, Patzer L, John U, Dušek J, Vondrák K, Janda J, et al. Blood pressure, renal function, and proteinuria in children with unilateral renal agenesis. Kidney Blood Pressure Res. 2006;29:210-5. https://doi.org/10.1159/000095735
PMid:16960459

7. Trihono PP, Wulandari N, Supriyatno B. Asymptomatic proteinuria in Indonesia adolescent students. Saudi J Kidney Dis Transpl. 2010;30:694-700. https://doi.org/10.4103/1319-2442.261347

8. Hilmanto D, Rossanti R. Sindrom nefrotik sensitif steroid. In: Rachmadi D, Sekarwana N, Hilmanto D, Garna H, editors. Buku Ajar Nefrologi Anak. Jakarta: IDAl; 2017. p. 213-12. https://doi. org/10.15395/mkb.v43n3.55

9. Edison M, Meunier M, Miller N. The evaluation of a 19-yearold with hypertension and proteinuria: $\mathrm{A}$ case report. J Primary Care Community Health. 2019;10:1-5. https://doi. org/10.1177/2150132719843437

PMid:31064291

10. Buyukacvi MA, Civilibal M, Elevli M, Selcuk Duru HN. Hypo-and hypervolemic edema in children with steroid sensitive nephrotic syndrome. Turk J Med Sci. 2015;45(1):178-83. https://doi. org/10.3906/sag-1312-130

PMid:25790549

11. Pramana $\mathrm{PD}$, Mayetti $\mathrm{M}$, Kadri $\mathrm{H}$. Hubungan antara proteinuria dan hipoalbuminemia pada anak dengan sindrom nefrotik yang dirawat di RSUP Dr. M. Djamil Padang periode 2009-2012. J Kesehatan Andalas. 2013;2(2):90-3. https://doi.org/10.25077/ jka.v2i2.127

12. Nilawati GA. Profil sindrom nefrotik pada ruang perawatan anak RSUP Sanglah Denpasar. Sari Pediatr. 2012;14(4):269-72. https://doi.org/10.14238/sp14.4.2012.269-72

13. Sudihardjo W, Prasetyo RV, Umijati S. Clinical profile of children with steroid-sensitive idiopathic nephrotic syndrome relapsing in the first year at Dr. Soetomo hospital, Surabaya. FMI. 2012;48:180-5.

14. Shatat IF, Becton LJ, Woroniecki RP. Hypertension in childhood nephrotic syndrome. Front Pediatr. 2019;7:287. https://doi. org/10.3389/fped.2019.00287

PMid:31380323

15. Ray EC, Rondon-Berrios H, Boyd CR, Kleyman TR. Sodium retention and volume expansion in nephrotic syndrome: Implications for hypertenion. Adv Chronic Kidney Dis. 2015;22(3):179-84. https://doi.org/10.1053/j.ackd.2014.11.006 PMid:25908466

16. Monthe KL, Liccioli G, Pela I. Blood pressure in children with minimal change nephrotic syndrome during oedema and after steroid therapy: The influence of familial essential hypertension. Kidney and Blood Pressure Res. 2009;32(4):258-62.https://doi. org/10.1159/000238823

PMid:1975257 